\title{
Juridical Review on Accountability of Implementing Village Income and Budget Allowance
}

\author{
${ }^{1}$ Agustien Cherly Wereh* \\ Law Studies Program \\ Faculty of Social Science \\ Universitas Negeri Manado \\ Tondano, Indonesia \\ cherlyagustienwereh@gmail.com
}

\author{
${ }^{2}$ Engeli Yuliana Lumaing \\ Law Studies Program \\ Faculty of Social Science \\ Universitas Negeri Manado \\ Tondano, Indonesia \\ engelilumaing@unima.ac.id
}

\begin{abstract}
This Republic of Indonesia Ministerial Regulation No.113 of 2014 concerning on village fund management Article 40 paragraph (1) and (2) states accountability report on the realization of APBDes as referred to in Articles 37 and 38 in written information to the public and media provided easily accessible to the public and information media referred in paragraph (1), among others, notice boards, community radio, and other information. However, the problem of human resources (HR) which is the village apparatus, still lacks accountability to manage APBdes, as well as the age and computer knowledge perspective, systematics to be implemented is quite difficult, which will be resulted irregularities village funds. The constitution tends to provide legal certainty because there are still violations. Is the accountability of the APBdes implemented transparently? The research objective is to identify the transparency of APBDes accountability. This research shows that regulating law has not able to function as expected, which made many village heads who are not transparent about the APBDes and made many deviations occur are detrimental to the State and communities.
\end{abstract}

Keywords: Transparency, Responsibility

\section{INTRODUCTION}

Law No.32 of 2004 Article 1 number (5), Regional Autonomy is a right, authority, and Based on the obligation of autonomous regions to self-regulate and manage government affairs and the interests of local communities by statutory regulations. Aside from being the lowest administrative unit in the Regency, it is also the forerunner to the formation of a nation and administration of the village government as a subsystem of the government administration system, to the village has the authority to regulate and manage its government affairs. The sustainability of community life can be realized if the village system in managing village finances is well managed by the village government.

The Government of Indonesia continues to strive to increase the implementation of national development to the pace of regional development and the pace of rural and urban development is more balanced and harmonious. However, national development in its implementation is faced with the main problems of development such as imbalances between villages and cities in Indonesia. This imbalance occurs because many factors influenced development in Indonesia are uneven and has an impact on high poverty in Indonesia.

Village development has a very important and strategic role in the framework of National and Regional Development, it contains elements of equitable development and its results. Also, village development can directly touch the interests of most of the people who live in rural areas to improve their welfare. In village development, village administration is a subsystem of the system of governance in Indonesia, to the village has the authority, duties, and obligations to regulate and manage the interests of its people.

Law No. 6 of 2014 concerning Villages is an interesting study material that is expected to strengthen village autonomy and accelerate development. Village level local authority units are also needed to conduct financial planning for village development implementation. In this area of budgeting, every village throughout Indonesia will receive funds whose budget calculations are based on the number of villages, taking into consideration the population, poverty rate, area size, and geographical difficulty level to improve the welfare and equitable development of villages.[1] The current problem is the quality of the human resources is the village apparatus is lack of village budget and income accountability accountable and certainly worthy of attention. Therefore, there needs to be transparency in the management of village funds to reduce the occurrence of irregularities in a village.

[2]Village Funds referred to in Article 1 paragraph (2) PP No. 60 of 2014 is the funds referred to Article 72 paragraph (2) of Law no. 6 of 2014 about Villages. The Village Fund is further explained in Government Regulation No. 43 of 2014 concerning Regulations for Implementing Law No. 6 of 2014 concerning Villages and Minister of Home Affairs Regulation No. 113 of 2014 concerning Village Financial Management, which states village financial management is a series of activities include planning, implementation, administration, reporting, and accountability.

In the ministerial regulation in the Republic of Indonesia No.113 of 2014 concerning village fund 
management article 40 paragraph (1) and (2) the realization report and the accountability report on the realization of the APBDesa implementation as referred to in articles (37) and (38) are communicated to the public in writing and information media are easily accessed by the public and the information media referred to paragraph (1) include announcement boards, community radio, and other information media.

A good strengthening of village financial management and supervision is necessary to prevent or at least reduce the possibility of irregularities and the realization of village development goals. There are still many village heads who are privately the village budget, they are not compliant with Law No. 14 of 2008 concerning disclosure of public information and Law no. 6 of 2014 concerning villages in article (27) letter (d) mentioned, a village head is required to provide and / or disseminate information on government administration in writing to the village community at the end of the fiscal year. The disclosure of information on village funds is a basic right for people in rural areas as stated in article 28 $\mathrm{f}$ of the 1945 Constitution which guarantees that citizens are no exception in rural areas to get access to information, especially related to village funds. This, of course, will increase the knowledge of rural communities and trigger a critical force which in turn encourages participation in development. Moreover, in the village law, the principle of openness is contained in articles (27) and (28), the principle of openness gives the community the right to obtain the correct information.

\section{RESEARCH METHODS}

This research method is empirical normative research. Empirical normative legal research uses empirical normative legal case studies in the form of legal behavior products. The subject of the study is the implementation or implementation of positive legal provisions and factual contracts on each particular legal event that occurs in the community to achieve predetermined goals.[3]

\section{RESULT AND DISCUSSION}

APBD is the basis for the management of regional finances within one fiscal year starting from January 1 to December 31. The Regional Head in the preparation of the APBD designates budget priorities and ceilings as the basis for the preparation of work plans and regional work unit budget. Based on the budget priorities and ceilings, the head of the regional work unit prepares the regional apparatus with the work performance approach to be achieved. The work plan and regional work unit budget are submitted to regional financial management officials as material to draft the Regional Regulation on the next year's APBD.[4]

According to Hans kelsen, the law is the norm. Norms are statements that suppress the "ought" or das sollen aspect, incorporating some rules on what to do. Norms are the original human product. The law of becommon traits provides guidance for individuals to act in society. The rules set a limit for people of the dakam burden or action against the individual. The existence of that rule and the performance of that rule resulted in legal certainty.

The normative certainty of the law is when a rule is made and enforced without order and logic, clear in the sense of having no doubt (multitafsir) and logical. It is clear in the sense that it becomes a system of norms with other ones so as not to clash or provoke conflict in them. Legal certainty points to a clear, consistent, consistent, consequences that result cannot affect the subjective circumstances. Certainty and justice are not merely moral demands, but they are characteristically characterize the law. A law that is uncertain and unwilling to be fair is not just a bad law.

According to utreecht, the certainty of the law contains two meanings: first, the rule of a public nature allows the individual to determine the actions of the right and wrong of the government, and second, the security of the law to the individual from the standpoint of public rule that the individual can know what to impose or impose upon the individual.

Certainty of the law is a guarantee of the law of justice. Norms that promote justice should actually function as rules that must be obeyed. According to gustav radbrunch justice and judicial certainty are a constant part of the law. He argued that the justice and certainty of the law should be attended to. Justice must be maintained in the name of a country's safety and order. Eventually the positive laws must always be obeyed.

According to Lawrence friedman, whether or not law enforcement is successful depends on:

a) the legal structure encompass the law, its counterpart and its system of law enforcement. The legal structure is strictly theoretical with the judicial system executed by law enforcement officials. How good an invite-law law is if it is not backed by a good law-enforcement apparatus, then justice is only wishful thinking.

b) legal content involves the content of the rule. Substance also means a product produced by those in the legal system includes decisions that they make. Not just a written rule but an unwritten one.

c) a legal culture consists of the cultural side in general, the customs of custom and opinion, real and thinking ways that appeal to social forces in society. A legal culture is the atmosphere of social thought and social force that determines how laws are used and, avoided, or abused. A legal culture is closely connected with the legal consciousness of society. The higher the legal consciousness of society will create a good law culture that can change people's interest in law over time. The level of public compliance with the law is one of the talk of law. 
From the above can mean that the functioning of a law is a sign that it has achieved the legal purpose of justice and judicial certainty. The level of effectiveness of the law is also determined by how high the level of public compliance with the law's dictates are made.

The current issue is the quality of the human resources of the village apparatus is still below the standard to be able to account for the income and expenditure budget of the village. The rights they have received. For this reason, the village head is obliged to implement the principles of governance which are accountable, transparent, professional, effective, and efficient, clean and free from collusion, corruption, and nepotism by the mandate of Law No. 6 of 2014 concerning Villages.

According to the researchers, the reporting mechanism should be conducted by the village apparatus is very difficult to understand and because of the HR education factors of the village apparatus are classified as low and the age factor can also be an obstacle in accountability of the village budget and income such as lack of knowledge in operating computers.

In-Law No. 6 of 2014 concerning Villages article 27 letter (d) stated, a village head is obliged to provide and/or disseminate information on the administration of government in writing to the village community at the end of each year, in Permendagri No. 113 of 2014 Article 39 states the accountability report on the implementation of the APBDes is an inseparable part of the report on the implementation of the Village Government.

It has become an obligation for the village head to be responsible for the revenue and study budgets, by Permendagri No.113 of 2014 concerning Village Fund Management article (40) paragraphs (1) and (2) which read "realization report and accountability report on implementation realization APBDes, as referred to in paragraphs (37) and (38), are informed to the public in writing and information media are easily accessible by the public and information media intended by paragraph (1) include notice boards, radio, communities, and other information media.

The law stipulates the accountability of the APBdes, but there are village heads who do not the command. There are still village heads who have not conducted transparent and accountable governance, by not providing information on village administration to the community of the misappropriation of the APBDes like corruption or embezzlement.

Based on this problem, the researchers certainly there is a blurring of norms in which the expectations of the law are not according to reality. The law regulates the obligations of a village head to provide information on the accountability of village funds to the village community because this information is the right of the community. There are still village heads who do conduct their obligations, causing a misappropriation of village funds to lead to corruption.

Transparency in accounting for village revenue and expenditure budgets certainly has become an obligation for village officials. The expectation from the Act on this matter turned out to be a reality not implemented yet. It turns out the governing law has not provided a sense of legal certainty which is one of the aims of the law itself.

Certainty is a matter (certain circumstances) provisions. The law should be certain and fair. It should be a code of conduct and fair due to the code of conduct should support an order considered reasonable. Only because it is fair and conducted certainty the law can fulfill its function. Legal certainty is a question only be answered normatively rather than sociology.[5]

\section{CONCLUSION}

Based on the results of research on the implementation of accountability for the village income and expenditure budget, not all villages are responsible for the transparent expenditure budget in terms of the quality of human resources who become village apparatuses who still lack to conduct responsibilities to implement transparent and accountable governance. And due to the community's critical power is very low to address things due to ignorance of their right in the form of all information regarding the administration of the government including the accountability of the village budget. People seem to do not care about the village apparatus. The legislative products regulate the problem do not meet legal certainty where the expectations of the Act are not implemented there are still elements in the village apparatus that violate these laws and regulations. Therefore, the implementation of the responsibility to the village income and expenditure budget has not been done transparently for the village community.

\section{ACKNOWLEDGMENT}

Thank you for Dean Faculty of Social Sciences for supporting this research.

\section{REFERENCES}

[1] Ivanovich Agusta, "Ketimpangan Wilayah Dan Kewajiban Dan Penanggulangan Di Indonesia. ” Jakarta, Swadaya Obor, 2014.

[2] Ivanovich Agusta, "Ketimpangan Wilayah Dan Kewajiban Dan Penanggulangan Di Indonesia”, Swadaya Obor, Jakarta, 2014, hal 45 No Title. Jakarta: Swadaya Obor, 2014.

[3] Peter Mahmud Marzuki, "Penelitian Hukum”,. Jakarta,: Kencana, 2008.

[4] Siswanto Sunarno, "Hukum Pemerintahan Daerah di Indonesia”,. Jakarta: Sinar Grafika, 2008.

[5] D. Rato, ," Filsafast Hukum Mencari Memahami hukum",,. Yogyakarta: Laksbang Pressindo, 2010. 